\title{
Cadmium resistance in an oligochaete and its effect on cadmium trophic transfer to an omnivorous shrimp
}

\author{
William G. Wallace ${ }^{1, *}$, Glenn R. Lopez ${ }^{2}$, Jeffrey S. Levinton ${ }^{3}$ \\ ${ }^{1}$ United States Geological Survey, Mail Stop 465, 345 Middlefield Road, Menlo Park, California 94025, USA \\ ${ }^{2}$ Marine Sciences Research Center, SUNY at Stony Brook, Stony Brook, New York 11794-5000, USA \\ ${ }^{3}$ Ecology and Evolution, SUNY at Stony Brook, Stony Brook, New York 11794-5245, USA
}

\begin{abstract}
It has been demonstrated that the deposit-feeding oligochaete Limnodrilus hoffmeisteri inhabiting Foundry Cove (FC), a severely cadmium (Cd)-contaminated cove located on the Hudson River, New York, USA, has evolved resistance to $\mathrm{Cd}$. In this study we investigate how this resistance influences $\mathrm{Cd}$ trophic transfer from this oligochaete to the grass shrimp Palaemonetes pugio. Cadmium-resistant worms collected from FC and nonresistant worms collected from an adjacent unpolluted site were investigated for differences in Cd tolerance, accumulation, subcellular distribution and bioavailability to shrimp. FC worms were more tolerant of $\mathrm{Cd}$, surviving twice as long as worms from the unpolluted site during a toxicity bioassay. The $7 \mathrm{~d}$ concentration factor of Cd-resistant worms was 4 times greater than that of nonresistant worms (2020 vs 577). There were also differences between worm populations with respect to subcellular $\mathrm{Cd}$ distributions. Cd-resistant worms produced metallothionein-like proteins (MT) as well as metal-rich granules (MRG) for Cd storage and detoxification; nonresistant worms only produced MT These differences in subcellular Cd distributions led to large differences in Cd bioavailability to shrimp; shrimp fed Cd-resistant worms absorbed $21 \%$ of the ingested $\mathrm{Cd}$, while those fed nonresistant worms absorbed roughly 4 times that amount $(\sim 75 \%)$. These absorption efficiencies were in good agreement with the proportions of $\mathrm{Cd}$ bound to the worm's most biologically available subcellular fractions (i.e. the cytosol and organelles). Although Cd-resistant worms predominantly stored the toxic metal in biologically unavailable MRG, their increased accumulation of $\mathrm{Cd}$ would still result in substantial trophic transfer to shrimp because of the storage of $\mathrm{Cd}$ in the biologically available fractions. This work demonstrates that the evolution of Cd resistance can have profound implications for Cd bioavailability and cycling within aquatic ecosystems.
\end{abstract}

KEY WORDS: Cadmium resistance $\cdot$ Detoxification $\cdot$ Trophic transfer $\cdot$ Oligochaetes $\cdot$ Grass shrimp

\section{INTRODUCTION}

Over the past few decades evidence has been mounting that populations evolve resistance in response to metal pollutants (Bradshaw 1952, Antonovics et al. 1971, Klerks \& Weis 1987) The impact of pollutant adaptations on ecosystems, in particular on processes such as pollutant trophic transfer, is not understood (Levinton 1980). The purpose of this and related studies was to determine how the evolution of cadmium (Cd) resistance in the aquatic oligochaete Lim-

·E-mail: wwallace@usgs.gov nodrilus hoffmeisteri influences $\mathrm{Cd}$ trophic transfer and toxicity to the benthic feeding grass shrimp Palaemonetes pugio (Klerks \& Levinton 1989, Klerks \& Bartholomew 1991, Wallace 1992, 1996, Wallace \& Lopez 1996, 1997).

Cadmium-resistant Limnodrilus hoffmeisteri, inhabiting the metal ( $\mathrm{Cd}, \mathrm{Cr}, \mathrm{Ni}$ )-contaminated Foundry Cove on the Hudson River, New York, USA, possess 2 means for detoxifying $\mathrm{Cd}$ : metallothionein-like proteins (MT) and metal-rich granules (MRG) (Klerks \& Levinton 1989, Klerks \& Bartholomew 1991) It is known that MT and MRG play important roles in the regulation, storage and detoxification of trace metals 
(Brown 1982, Roesijadi 1992). By using the detoxification of $\mathrm{Cd}$ by $L$. hoffmeisteri and Palaemonetes pugio as a predator, the aim of this research is to determine the importance of these divergent detoxification pathways in controlling metal trophic transfer.

The storage of metal via proteins (including MT) and MRG can control metal bioavailability to predators. Copepods and bivalve larvae fed phytoplankton, and grass shrimp fed oligochaetes absorbed all of the metal associated with cytoplasm and cytosol, while metal bound to cell walls, tissue and MRG was less available (Reinfelder \& Fisher 1991, 1994, Wallace \& Lopez 1996, 1997). Bioavailability to predators of $\mathrm{Zn}, \mathrm{Mn}$ and $\mathrm{Mg}$ stored in granules of gastropods depends upon granule elemental composition; metal was less available in phosphate granules than in carbonate granules (Nott \& Nicolaidou 1989, 1990,

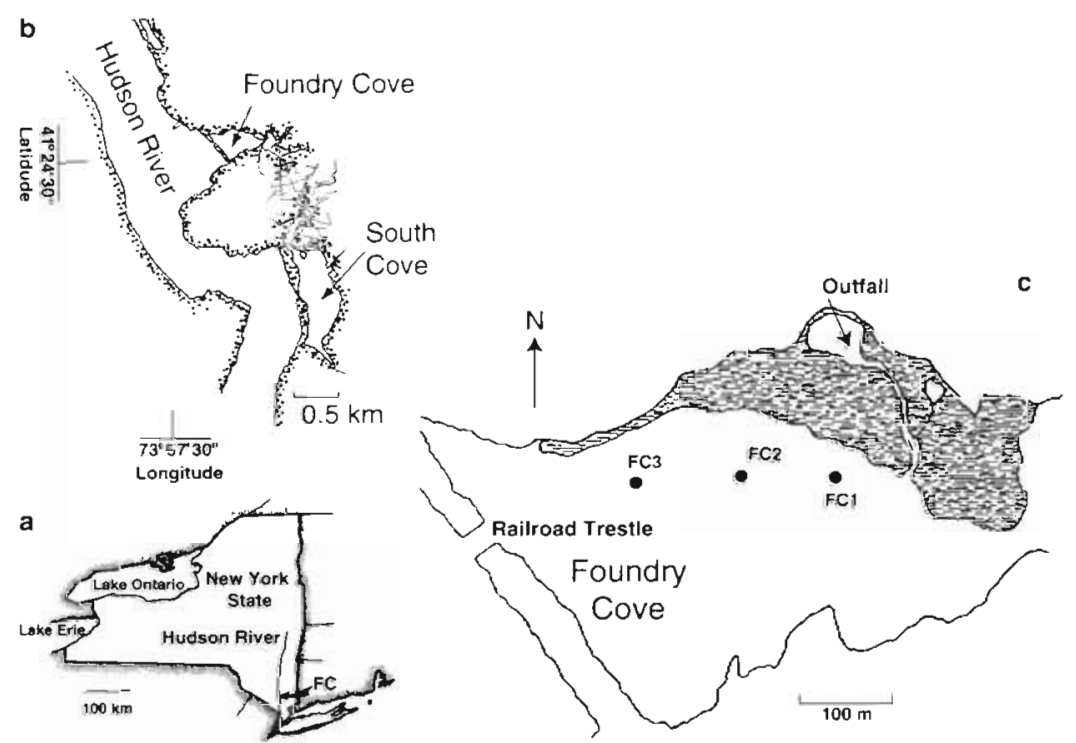

Fig. 1 Maps indicating geographic location of study sites (Foundry and South Coves) ( $\mathrm{a} \& \mathrm{~b}$ ) and locations within Foundry Cove (FC 1, FC 2 and FC 3) where sediment and oligochaetes were collected for use in $\mathrm{Cd}$ accumulation and trophic transfer studies (c). Site of the former battery plant outfall is also 1993). indicated

Exposure conditions control metal uptake and storage, and chronic, long-term exposure can result in increased metal tolerance and even resistance (Klerks \& Weis 1987, Roesijadi \& Klerks 1989, Mason \& Jenkins 1991, Brouwer et al. 1992, Canli \& Furness 1995, Wallace \& Lopez 1996). In some instances metal resistance results in the internal storage and detoxification of metal, and can lead to increased metal body burdens (Bryan \& Hummerstone 1971, Brown 1977, Klerks \& Bartholomew 1991). Increased metal body burdens and accompanying changes in subcellular metal distributions can therefore profoundly affect metal cycling within aquatic ecosystems.

The study site for this work, Foundry Cove, near Cold Spring, New York, is a fresh-to-brackish-water cove located on the Hudson River, and represents a unique opportunity for studying the effects of $\mathrm{Cd}$ in an aquatic ecosystem (Fig. 1). This cove was polluted with $\mathrm{Cd}, \mathrm{Ni}$ and $\mathrm{Co}$ by effluent discharged from a $\mathrm{Ni}-\mathrm{Cd}$ battery plant between 1953 and 1979, and until the fall of 1994 when the cove was dredged, Foundry Cove was one of the most severely Cd-contaminated sites in the world (Simpson 1981, Resource Engineering 1983). Much of the sediment contained up to $500 \mu \mathrm{g} \mathrm{Cd} \mathrm{g}$ dry $w^{-1}$, with the most polluted area, the outfall site, having concentrations as high as $225000 \mu \mathrm{g} \mathrm{Cd} \mathrm{g} \mathrm{dry}$ wt $^{-1}$ ( $22 \%$ Cd on a dry wt basis) (Knutson et al. 1987, Klerks \& Levinton 1989). Cadmium in the sediment near the outfall was mostly present as a relatively insoluble $\mathrm{Ca}-\mathrm{Cd}$ carbonate, while in the middle regions of the cove $\mathrm{Cd}$ was predominantly associated with organic material (Bower et al. 1978). Concentrations of $\mathrm{Ni}$ and $\mathrm{Co}$ in the cove were also very high, reaching as high as 21100 and $437 \mu \mathrm{g} \mathrm{g}$ dry $\mathrm{wt}^{-1}$, respectively (Knutson et al. 1987).

Cadmium accumulated in the biota of the cove, both animals and plants, but the consumption of contaminated blue crabs Callinectes sapidus appeared to be the only likely source of $\mathrm{Cd}$ exposure from aquatic food sources to human residents in the area (Kneip \& Hazen 1979, Hazen \& Kneip 1980, Klerks \& Bartholomew 1991). The severity of the contamination was highlighted in 1981 when Foundry Cove was designated a Superfund site (i.e. being eligible for specific remediation funds) by the United States Environmental Protection Agency. To remove the estimated 12 metric tons of $\mathrm{Cd}$ remaining of the original 22 metric tons deposited in the cove, a major remediation project was initiated in the fall of 1993.

This dredging project commenced soon after the collection of samples that were used in portions of this study. Therefore, the research presented here was conducted with laboratory-cultured oligochaetes. South Cove, adjacent to and down river from. Foundry Cove, was the control site for this study. This cove did not directly receive the waste effluent and is comparatively clean, though sediment $\mathrm{Cd}$ concentrations reach as high as $20 \mu \mathrm{g} \mathrm{g}$ dry $\mathrm{wt}^{-1}$, demonstrating that $\mathrm{Cd}$ entering the Hudson River from Foundry Cove was being exported to other areas (Klerks 1987); uncontaminated sediments rarely have $\mathrm{Cd}$ concentrations exceeding $1 \mu \mathrm{g} \mathrm{g}$ dry $\mathrm{wt}^{-1}$ (Simpson 1981, Sadiq 1992). 
The deposit-feeding oligochaete Limnodrilus hoffmeisteri is the one of the most abundant and widely distributed tubificid oligochaetes inhabiting the fresh to brackish waters of the Hudson River (Brinkhurst \& Jamieson 1971), and it is the most abundant macrofaunal organism inhabiting Foundry Cove sediments (Klerks \& Levinton 1989). In some areas of Foundry Cove L. hoffmeisteri have evolved resistance to $\mathrm{Cd}$ (Klerks \& Levinton 1989). Adaptation has resulted in high $\mathrm{Cd}$ body burdens, resulting from $\mathrm{Cd}$ binding to MT-like proteins and precipitation into MRG, believed to be CdS (Klerks \& Bartholomew 1991). Genetic studies have indicated that resistance evolved within 4 to 36 generations and is under the control of one gene (Klerks \& Levinton 1989, Martinez \& Levinton 1996). This resistance also varies with sediment Cd concentrations (Klerks \& Levinton 1989). Foundry Cove $L$. hoffneisteri was therefore an ideal prey species to investigate how chronic metal exposure and the evolution of metal resistance alters metal trophic transfer.

The predator used in these studies, the grass shrimp Palaemonetes pugio, is distributed along the Atlantic and Gulf Coasts of the United States, has a salinity tolerance of 2 to 35 psu and is an abundant benthic omnivore in marsh-cove ecosystems (Wood 1967. Knowlton 1973, Williams 1974, Welsh 1975). P. pugio feeds on benthic invertebrates, including oligochaetes, and is an important link in coastal food chains (Welsh 1975, Bell \& Coull 1978). This shrimp is a favorite prey item of many ecologically and recreationally important species (i.e. Fundulus heteroclitus, Callinectes sapidus, Pseudopleuronectes americanus, Pomatomus saltatrix, Anguilla rostrata, Roccus americanus), and if exposed to a contaminated diet, may serve as a vector of pollutants to higher trophic levels (Nixon \& Oviatt 1973, Hoffman 1980). P. pugio is abundant in Foundry and South Coves during periods of low river flow when salinities are $\sim 5$ psu (W. G. Wallace pers, obs.) and for these reasons was chosen as a representative predator for use in this study.

In this study we investigate how chronic $\mathrm{Cd}$ exposure and the evolution of Cd resistance in Limnodrilus hoffmeisteri influences $\mathrm{Cd}$ trophic transfer to Palaemonetes pugio. This was accomplished by determining the relationships between Cd resistance, accumulation and subcellular distributions in Cd-resistant and nonresistant oligochaetes and understanding how these differences influence $\mathrm{Cd}$ trophic transfer from oligochaetes to shrimp.

\section{MATERIALS AND METHODS}

Field sampling, sediment cores and worm cultures. In October 1993, 3 sediment cores and -401 of bulk sediment (wet) were collected from 3 stations (FC 1 , FC 2 and FC 3 ) along the spatial gradient of Cd contamination in Foundry Cove (Fig. 1c). Based on previous studies (Kniep \& Hazen 1979, Knutson et al. 1987, Klerks \& Levinton 1989, R. R. Young unpubl.), study sites were chosen to encompass a gradient of sediment Cd levels ranging from $1500 \mu \mathrm{g} g$ dry $\mathrm{wt}^{-1}$ and higher to less than $500 \mu \mathrm{g} \mathrm{g} \mathrm{dry} \mathrm{wt}^{-1}$. Sediment cores and bulk sediment samples were returned to the laboratory in buckets containing overlying water collected in the cove, and were stored $\left(10^{\circ} \mathrm{C}\right)$ with gentle aeration.

To obtain Limnodrilus hoffmeisteri for laboratory cultures, bulk sediment was sieved through a $500 \mu \mathrm{m}$ screen and organisms were picked from the retained detrital material. Oligochaetes and sediment from the 3 Foundry Cove stations (FC 1, FC 2 and FC 3) and from South Cove (SC) were maintained in laboratory cultures according to Bonacina et al. (1989). The cultures consisted of plastic containers $(23 \times 40 \mathrm{~cm})$ containing $2.5 \mathrm{l}$ of cove water and a $2 \mathrm{~cm}$ layer of sediment. The sediment was wet sieved to the $<240 \mu$ m fraction with Hudson River water. Ground commercial fish food (Tetramin ${ }^{\circledR}$ ) was added weekly to the cultures. The cultures were maintained at $23^{\circ} \mathrm{C}$ under a 12 h light: 12 h dark photoperiod.

Sediment cores were processed under a nitrogen atmosphere in the following manner: the upper $6 \mathrm{~cm}$ of each core was extruded and sliced at $2 \mathrm{~cm}$ intervals $(0-2,2-4$ and $4-6 \mathrm{~cm})$; sections were homogenized and samples ( $3 \mathrm{ml} ; 1 \mathrm{~g}$ of dry wt sediment) were taken for analysis of $\mathrm{Cd}$ and for the determination of wet weight/dry weight ratios. Sediment samples were also taken from laboratory worm cultures (see below) and were treated and analyzed in the same manner as those collected from cores

$\mathrm{Cd}$ was extracted from wet sediment by digestion with $0.02 \mathrm{M} \mathrm{HNO}_{3}(\mathrm{pH} 2)$ and $30 \% \mathrm{H}_{2} \mathrm{O}_{2}\left(85^{\circ} \mathrm{C}\right.$ for $\left.2 \mathrm{~h}\right)$. After cooling, $3.2 \mathrm{M} \mathrm{NH}_{4} \mathrm{OCH}_{3} \mathrm{COOH}$ in $3 \mathrm{MI} \mathrm{HNO}_{3}$ was added to prevent readsorption of extracted metal to the oxidized sediment (Tessier et al. 1979). Extractions were conducted in centrifuge tubes to minimize losses, and supernates were collected by centrifugation at $12000 \times g$ for $30 \mathrm{~min}$. Supernates were then filtered through $0.45 \mu \mathrm{m}$ membrane filters and stored $\left(4^{\circ} \mathrm{C}\right)$ until analysis by flame atomic absorption spectrophotometry (Perkin-Elmer Zeeman/5000 Atomic Absorption Spectrophotometer equipped with an HGA500 graphite atomizer and an AS-40 autosampler). Recovery of reference material (MESS-1, National Research Council, Canada) approximated 100\%. Wet wt/dry wt ratios were determined by dividing wet sample weights by dry sample weights (constant wt at $60^{\circ} \mathrm{Cj}$. All materials used for $\mathrm{Cd}$ analysis were acid washed with $1.6 \mathrm{M} \mathrm{HNO}_{3}$ and rinsed with distilled water. 
Cadmium resistance determinations. Differences in Cd tolerance among worm populations were determined by conducting toxicity tests in which worms were exposed to $8.9 \mu \mathrm{M} \mathrm{Cd}\left(\sim 1 \mathrm{ppm}\right.$ ) (added as $\mathrm{CdCl}_{2}$ ) in soft reconstituted fresh water (ASTM 1980, Klerks 1987). This exposure concentration, although unrealistically high, was chosen because previous work has shown that survival times are long enough to detect differences in Cd resistance yet short enough to avoid stresses due to living out of sediment (Klerks 1987). As a comparison, the $96 \mathrm{~h} \mathrm{LC}_{50}$ for Limnodrilus hoffmeisteri is $170 \mathrm{\mu g}^{-1}$ (Chapman et al. 1982). Toxicity tests were only conducted with worms from FC 1 and SC because the cultures of FC 2 and FC 3 worms did not thrive under the laboratory culture conditions; the dredging of Foundry Cove negated the possibility of reestablishing these cultures.

Worms were removed from the cultures, allowed to evacuate gut contents in soft reconstituted fresh water $(\sim 24 \mathrm{~h})$ and placed individually in well dishes $(2.2 \mathrm{~cm}$ diameter) containing $4 \mathrm{ml}$ of the test solution. Well dishes were covered to prevent evaporation, and worms (96 from each site) were checked hourly for survivors. A worm was scored as dead when it did not respond to a gentle disturbance with a pipet (Klerks 1987). Worms were monitored until 50\% from each population had died. Differences in Cd tolerance were determined by pair-wise comparisons of survivorship curves using Gehan's Generalized Wilcoxon Test (Lee 1980). This test compares 2 survivorship curves and is appropriate for use with partial data sets.

Cadmium accumulation by oligochaetes. Cadmium accumulation by FC 1, FC 2, FC 3 and SC Limnodrilus hoffmeisteri was investigated by exposing worms to ${ }^{109} \mathrm{Cd}$ for $7 \mathrm{~d}$, then calculating weight-normalized concentration factors. Worms were removed from the cultures, allowed to evacuate gut contents in Hudson River water $(\sim 24 \mathrm{~h})$, then placed in flasks containing $150 \mathrm{ml}$ of the labeling solution. There were 6 replicates per station with 8 worms per replicate. The labeling solution was prepared by adding a trace amount of ${ }^{109} \mathrm{Cd}\left(0.7 \mathrm{ng} \mathrm{l}{ }^{-1} ; 24 \mathrm{kBq} \mathrm{l}^{-1}\right)$, added as ${ }^{109} \mathrm{CdCl}_{2}$ in $0.1 \mathrm{M}$ $\mathrm{HCl}$, to $0.2 \mu \mathrm{m}$ (Nuclepore ${ }^{(1)}$ ) filtered Hudson River water ( 0 psu). The acidification of the labeling solution caused by the addition of the label $\left({ }^{109} \mathrm{CdCl}_{2}\right.$ in $0.1 \mathrm{M}$ $\mathrm{HCl}$ ) was offset by the addition of $1 \mathrm{M} \mathrm{NaOH}$. The Hudson River water was estimated as having a background $\mathrm{Cd}$ concentration of approximately $0.5 \mu \mathrm{g} \mathrm{Cd}$ $\mathrm{l}^{-1}$ (Wallace \& Lopez 1996). After the $7 \mathrm{~d}$ exposure to ${ }^{109} \mathrm{Cd}$, worms were removed from solution, rinsed with distilled water, individually weighed and assayed for ${ }^{109} \mathrm{Cd}$. Worms were then stored frozen $\left(-80^{\circ} \mathrm{C}\right)$ for use in subsequent subcellular fractionations. Samples of the labeling solution were also assayed for ${ }^{109} \mathrm{Cd}$. Concentration factors were calculated by dividing the
${ }^{109} \mathrm{Cd}$ concentration of the worm $\left({ }^{109} \mathrm{Cd} \mathrm{g}\right.$ wet $\left.\mathrm{wt}^{-1}\right)$ by the ${ }^{109} \mathrm{Cd}$ concentration of the water $\left({ }^{109} \mathrm{Cd} \mathrm{ml} \mathrm{m}^{-1}\right)$.

Subcellular cadmium distributions. Differences in oligochaete subcellular ${ }^{109} \mathrm{Cd}$ distributions were investigated by homogenizing the worms from the aforementioned $\mathrm{Cd}$ accumulation experiment and subjecting the homogenate to differential centrifugation and tissue digestion procedures. Some of the laboratory cultured worms (FC 1 and FC 3) were also investigated for subcellular distributions of stable Cd.

Worms from the accumulation experiment were thawed and homogenized in $0.5 \mathrm{ml}$ distilled water with a glass tissue homogenizer; there were 4 samples per treatment, each consisting of roughly 8 worms. After homogenization, the homogenates from one FC 1 replicate and one $\mathrm{SC}$ replicate were split; one portion from each was reserved $\left(-80^{\circ} \mathrm{C}\right)$ for use in feeding experiments; the other portions as well as the unseparated SC, FC 1, FC 2 and FC 3 samples were fractionated according to the procedure in Fig. 2. Homogenized worms were first fractionated by centrifugation at $300 \times g\left(15 \mathrm{~min}\right.$ at $\left.4^{\circ} \mathrm{C}\right)$. This produced a pellet containing tissue fragments and other cellular debris (i.e. membranes, setae and MRG). MRG were isolated from tissue fragments by resuspending the pellet in $0.5 \mathrm{ml}$ distilled water and heating at $100^{\circ} \mathrm{C}$ for $2 \mathrm{~min}$. An equal volume of $1 \mathrm{~N} \mathrm{NaOH}$ was then added, followed by heating at 60 to $70^{\circ} \mathrm{C}$ for $1 \mathrm{~h}$. This procedure dissolved the tissue, and MRG were then collected by

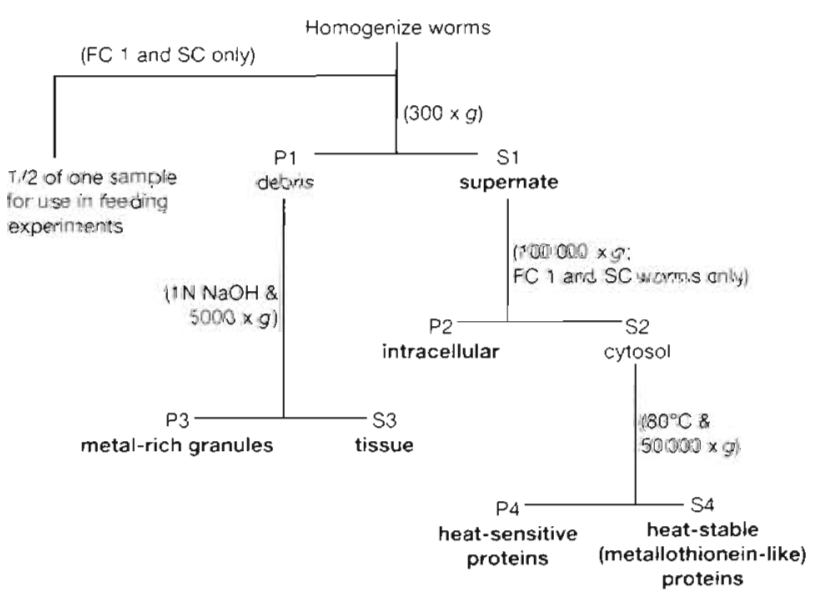

Fig. 2. Procedure for obtaining subcellular ${ }^{109} \mathrm{Cd}$ distributions of Limnodrilus hoffmeisteri. Worms were homogenized, and differential centrifugation and tissue digestion procedures were used to obtain the following subcellular fractions: metalrich granules (MRG), tissue, supernate (intracellular/cytosol) The supernates of South Cove (SC) and Foundry Cove (FC 1) worms were further fractionated into intracellular, and heatsensitive and heat-stable (MT-like) proteins. Prior to centrifugation half of the homogenate from one sample of FC 1 and one sample of $\mathrm{SC}$ worms were reserved for use in feeding experiments 
centrifugation at $5000 \times g\left(10 \mathrm{~min}\right.$ at $\left.20^{\circ} \mathrm{C}\right)$. The pellet was resuspended and rinsed several times with $1 \mathrm{~N}$ $\mathrm{NaOH}$ (Silverman et al. 1983). Isolated granules were then examined via compound microscopy.

The $300 \times g$ supernates were either left unfractionated (FC 2 and $F C$ ) or were further centrifuged ( $F C 1$ and $\mathrm{SC})$ at $100000 \times g\left(1 \mathrm{~h}\right.$ at $\left.4^{\circ} \mathrm{C}\right)$ to produce an intracellular pellet containing nuclear, mitochondrial and microsomal fractions; the $100000 \times g$ supernate contained the cytosol and included proteins (Fig. 2). The cytosol of FC 1 and SC worms was fractionated into heat-stable (MT-like) proteins and heat-sensitive proteins. Preliminary work showed that heat-sensitive proteins could not be collected from a homogenate of 8 worms (pellets were too small); therefore, all of the cytosolic samples obtained from FC 1 worms were combined prior to heat treatment. The cytosolic samples of SC worms were also combined. Composite samples were heat denatured at $80^{\circ} \mathrm{C}$ for $10 \mathrm{~min}$. Samples were then cooled on ice for $1 \mathrm{~h}$. Heat-sensitive proteins were separated from the heat-stable fraction by centrifugation at $50000 \times g\left(10 \mathrm{~min}\right.$ at $\left.4^{\circ} \mathrm{C}\right)(\mathrm{Be}-$ bianno \& Langston 1992). Percentage subcellular ${ }^{109} \mathrm{Cd}$ distributions were estimated based on total recovered radioactivities; previous work has shown that recovery of initial Cd is high $(-90 \%)$ (Wallace \& Lopez 1996 , 1997).

To verify that ${ }^{109} \mathrm{Cd}$ followed the distribution of stable $\mathrm{Cd}$, the subcellular distribution of stable $\mathrm{Cd}$ within oligochaetes was determined as follows. Approximately 100 worms from FC 1 and FC 3 were removed from the cultures and were allowed to depurate gut contents. Worms were then wet weighed in bulk $(\sim 125 \mathrm{mg}$ per group) and homogenized in $1.75 \mathrm{ml}$ distilled water. Homogenates were then centrifuged at $300 \times g\left(15 \mathrm{~min}\right.$ at $4^{\circ} \mathrm{C}$ ). Supernates (cytosolic and intracellular fractions) and pellets (MRG and tissue fractions) were prepared for $\mathrm{Cd}$ analysis by adding $8 \mathrm{M}$ $\mathrm{HNO}_{3}$, refluxing at $95^{\circ} \mathrm{C}$ for $10 \mathrm{~min}$, in glass beakers, after which $16 \mathrm{M} \mathrm{HNO}_{3}$ was added and samples were refluxed for an additional $30 \mathrm{~min}$. After refluxing, 30\% $\mathrm{H}_{2} \mathrm{O}_{2}$ was added and the samples were heated a second time. Digested samples were then filtered and analyzed for Cd by flame atomic absorption spectrophotometry. The $\mathrm{Cd}$ concentration in each fraction was calculated on a wet weight basis and percentage $\mathrm{Cd}$ distributions were estimated based on the total recovered $\mathrm{Cd}$. All materials and utensils used for $\mathrm{Cd}$ analysis were washed with $1.6 \mathrm{M} \mathrm{HNO}_{3}$ and rinsed with distilled water.

Bioavailability of cadmium sequestered by oligochaetes. The portions of the homogenates from FC 1 and SC worms reserved prior to subcellular fractionation (see above) were freeze dried and mixed with $0.05 \mathrm{ml}$ distilled water. Fractions were then mixed (1:4) with a gelatin solution prepared from $0.6 \mathrm{~g}$ gelatin crystals (Knox ${ }^{\circledR}$ ) and $10.5 \mathrm{ml}$ distilled water (Wallace \& Lopez 1996, 1997). Aliquots $(6 \mu l)$ of the homogenate/ gelatin slurry were pipetted onto pre-chilled $0.2 \mu \mathrm{m}$ polycarbonate membrane filters and were stored frozen $\left(-20^{\circ} \mathrm{C}\right)$. The 'gelatin discs' on these filters were then fed to shrimp. Previous work has shown that this method does not alter Cd bioavailability; shrimp fed whole worms or homogenized worms mixed with gelatin absorb similar amounts of ingested Cd (Wallace \& Lopez 1996, 1997).

Grass shrimp Palaemonetes pugio and water collected from Great South Bay, Long Island, New York, were returned to the laboratory and placed in glass aquaria. Over the course of 1 wk shrimp were slowly acclimated from a field salinity of $\sim 20$ psu to the experimental salinity of 5 psu. A salinity of 5 psu was chosen because it is the highest noted in Foundry Cove and is within the salinity tolerance of the shrimp (Wood 1967, Bower et al. 1978). After acclimation shrimp were held for an additional $7 \mathrm{~d}$ period (20 to $23^{\circ} \mathrm{C}$ ). Shrimp were fed daily on Tetramin ${ }^{\circledR}$ fish food, but 2 d prior to the feeding experiment food was withheld. Because our previous work has shown that the feeding activity of these shrimp is extremely variable, even after a period of food deprivation, this feeding experiment was initiated by placing 25 shrimp in a large glass petri dish $(20 \mathrm{~cm}$ ) containing a $3 \mathrm{~cm}$ layer of seawater with a subsequent addition of only 14 gelatin discs. The shrimp that were most eager to feed would grab one of the gelatin discs and rapidly consume it ( $\sim$ to $10 \mathrm{~min})$; only those shrimp ingesting a majority (>90\%) of a gelatin disc were used for subsequent ${ }^{109} \mathrm{Cd}$ analysis.

After ingesting the worm/gelatin mix, shrimp (10 per treatment) were rinsed with distilled water, placed into gamma counting tubes containing $5 \mathrm{ml}$ seawater, and assayed for ${ }^{109} \mathrm{Cd}$. Shrimp were then transferred to holding chambers, consisting of a mesh-bottomed cylinder and a fecal collector, where they were allowed to feed ad libitum on squid tissue (Wallace \& Lopez 1997). Chambers were maintained in a glass aquarium containing 40 l of seawater that was continuously aerated and passed through an aquarium filter containing activated carbon and filter media. Over the next $6 \mathrm{~d}$ shrimp were periodically assayed for ${ }^{109} \mathrm{Cd}$. The amount of egested ${ }^{109} \mathrm{Cd}\left({ }^{109} \mathrm{Cd}\right.$ in fecal material) was determined by periodically filtering the contents of the chamber's fecal collector onto GF/C glass fiber filter and assaying the filter for ${ }^{109} \mathrm{Cd}$.

Radioanalysis. All samples were placed in $11.5 \mathrm{ml}$ polypropylene test tubes and analyzed for ${ }^{109} \mathrm{Cd}$ by determining photon emissions at $88 \mathrm{keV}$ in a Pharmacia-Wallac LKB automated gamma counter equipped with an NaI crystal. Counting times were usually $5 \mathrm{~min}$ and propagated counting errors were kept below $10 \%$. 

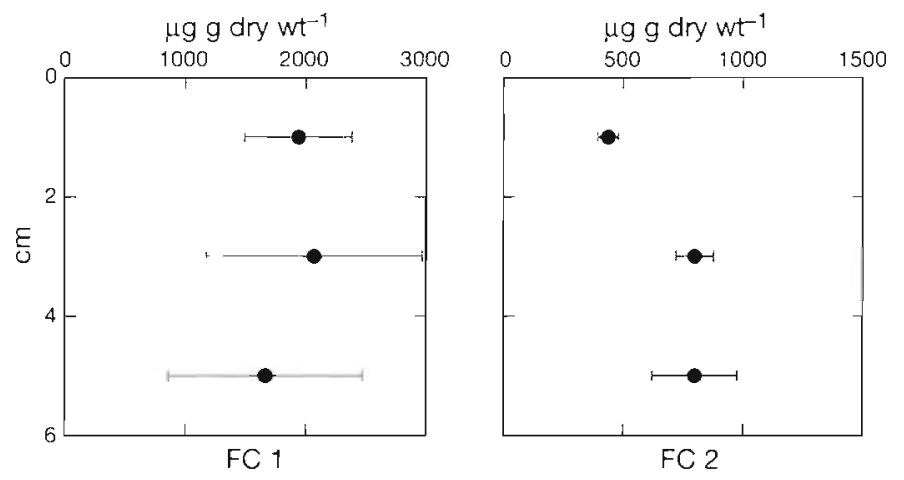

\section{RESULTS}

\section{Sediment cores and worm cultures}

Profiles of sedimentary-bound $\mathrm{Cd}$ for the 3 Foundry Cove stations (FC 1, FC 2 and $F C 3$ ) are shown in Fig. 3. FC 1 had the highest $\mathrm{Cd}$ concentration at $\sim 2000 \mu \mathrm{g} \mathrm{g}$ dry $\mathrm{wt}^{-1}$, and concentrations were relatively uniform over the sampling depth. Cadmium concentrations at stations FC 2 and FC 3 were much lower and increased with depth from $-400 \mu \mathrm{g} \mathrm{g}$ dry $\mathrm{wt}^{-1}$ in the surface layer $\left(0\right.$ to $2 \mathrm{~cm}$ ) to $-800 \mu \mathrm{gg} \mathrm{g}$ dry $\mathrm{wt}^{-1}$ in deeper sediments $(2$ to $6 \mathrm{~cm})$ for $\mathrm{FC} 2$ and from $\sim 250$ to $\sim 500 \mu \mathrm{g} \mathrm{g}$ dry $\mathrm{wt}^{-1}$ for similar depth intervals for FC 3 . Sediment $\mathrm{Cd}$ concentrations from the 3 worm cultures (FC 1, FC 2 and FC 3) were, respectively, 386, 358 and $231 \mu \mathrm{g} \mathrm{g}$ dry $\mathrm{wt}^{-1}$, and with the exception of FC 1 , were similar to those found in the surface sediments 10 to $2 \mathrm{~cm}$ ) from the respective stations.

\section{Cadmium resistance determinations}

Upon exposure to $8.9 \mu \mathrm{M} \mathrm{Cd}, \mathrm{FC} 1$ worms survived significantly longer ( $<<0.001)$ than SC worms (Fig. 4). $\mathrm{SC}$ worms started dying after $7 \mathrm{~h}$ of exposure, after which there was a constant loss of individuals $(-3.6 \%$ $h^{-1}$ ). FC 1 worms did not start to succumb to the $\mathrm{Cd}$ exposure until after $16 \mathrm{~h}$ and there was only a loss of approximately $10 \%$ in the nexl $9 \mathrm{~h}\left(-1.1 \% \mathrm{~h}{ }^{1}\right)$. After $25 \mathrm{~h}$, the mortality rate for FC 1 worms increased dramatically $\left(\sim 8 \% \mathrm{~h}^{-1}\right)$. The median survival times for FC 1 and SC worms were 30 and $21 \mathrm{~h}$, respectively.

\section{Cadinium accumulation by oligochaetes}

Accumulation of ${ }^{109} \mathrm{Cd}$ by oligochaetes depended upon site of collection and increased with sediment $\mathrm{Cd}$ exposure (Fig. 5). Foundry Cove worms came from sediment having large differences in $\mathrm{Cd}$ contamination, but there were no differences in mean $7 \mathrm{~d}$ con-

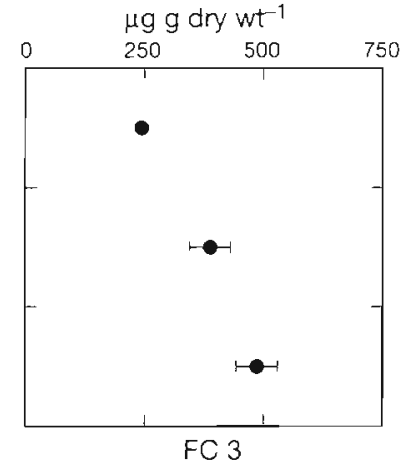

Fig. 3. Cd depth profiles ( $\mu \mathrm{g} g$ dry wet $w t^{-1}, \mathrm{n}=3$; mean $\pm \mathrm{SE}$ from 3 Foundry Cove stations (FC 1, FC 2, and FC 3). Sediment cores were sliced at $2 \mathrm{~cm}$ intervals and $\mathrm{Cd}$ concentrations were determined by sediment digestion procedures and atomic absorption spectrophotometry. Note difference in scales among the 3 profiles centration factors among worms from the 3 sites Worms from all Foundry Cove sites (FC 1, FC 2 and FC 3) exhibited similar mean concentration factors, $(2020,2180,2253$, respectively) that were significantly higher $(\mathrm{p}<0.001)$ than the concentration factor of 577 for SC worms. This lack of a difference among concentration factors of Foundry Cove worms can be explained by a few high values for FC 2 and FC 3 worms; this is apparent from the large difference between the means and medians for these 2 stations. Further examination of concentration factors among worms from the 3 Foundry Cove stations reveals that there is a significant ( $p<0.05$; Jonckheere's ordered alternatives test) increase in $\mathrm{Cd}$ accumulation along the gradient.

\section{Subcellular cadmium distributions}

Oligochaetes from all Foundry Cove stations had similar distributions of subcellular ${ }^{109} \mathrm{Cd}$ with -30 to

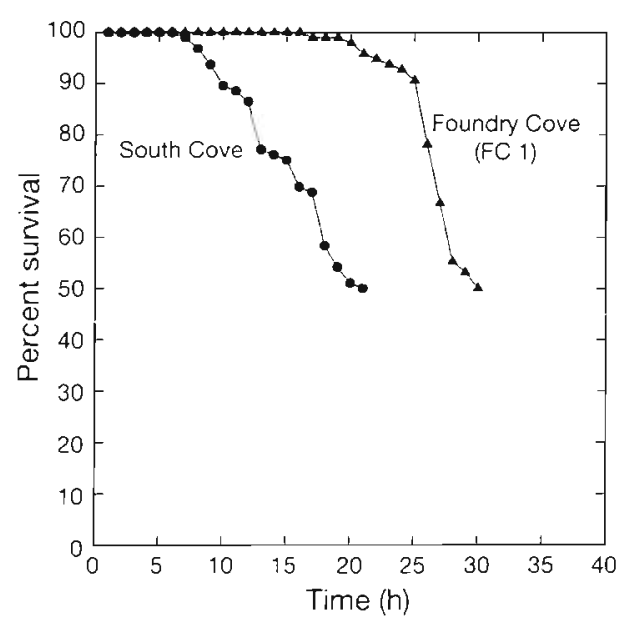

Fig. 4. Limnodrilus hoffmeisteri. Survivorship curves (percentage) for South Cove ( ) and Foundry Cove (FC 1) ( 4 ) worms exposed to $8.9 \mu \mathrm{M} \mathrm{Cd}$ in soft reconstituted fresh water. Worms were checked hourly for survivors, and the toxicity test was terminated after worms from each station experienced $50 \%$ mortality 


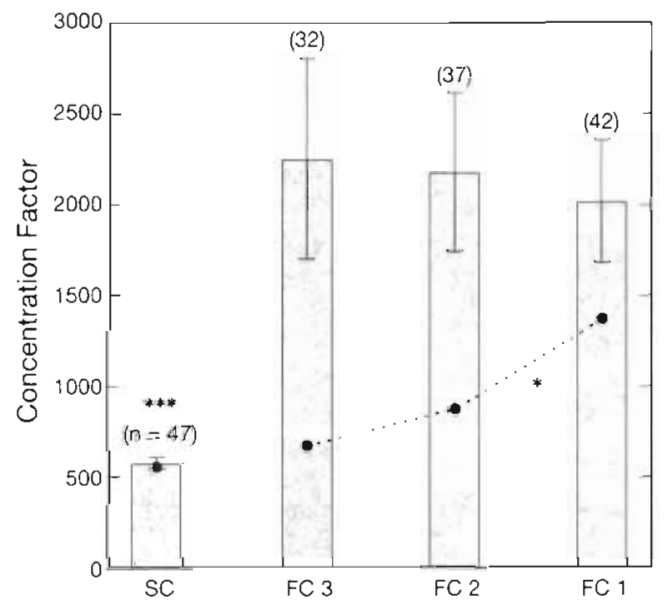

Fig. 5. Limnodrilus hoffmeisteri. Accumulation of ${ }^{109} \mathrm{Cd}$ by worms collected from South Cove (SC) and 3 Foundry Cove stations (FC 3, FC 2 and FC 1). Worms were exposed for $7 \mathrm{~d}$ to filtered Hudson River water containing a spike $\left(24 \mathrm{kBq} \mathrm{l^{-1 }}\right)$ of ${ }^{109} \mathrm{Cd}$. Seven day concentration factors (bars are means $\pm \mathrm{SE}$; dots are medians) were calculated by dividing the concentration of ${ }^{109} \mathrm{Cd}$ in worms by the concentration of ${ }^{109} \mathrm{Cd}$ in the water. The concentration factor for SC worms was significantly ( $\cdots p<0.001$ ) lower than that for worms from the other stations. The dashed line connecting the median concentration factors of Foundry Cove worms represents a significant $(" p<0.05$; Jonckheere's ordered alternatives test) increase in

$\mathrm{Cd}$ accumulation along the contamination gradient

$40 \%$ being distributed among each of the 3 main subcellular fractions (MRG, tissue and intracellular) cytosolic [i.e. supernate of $300 \times$ g]) (Fig. 6). The sub-

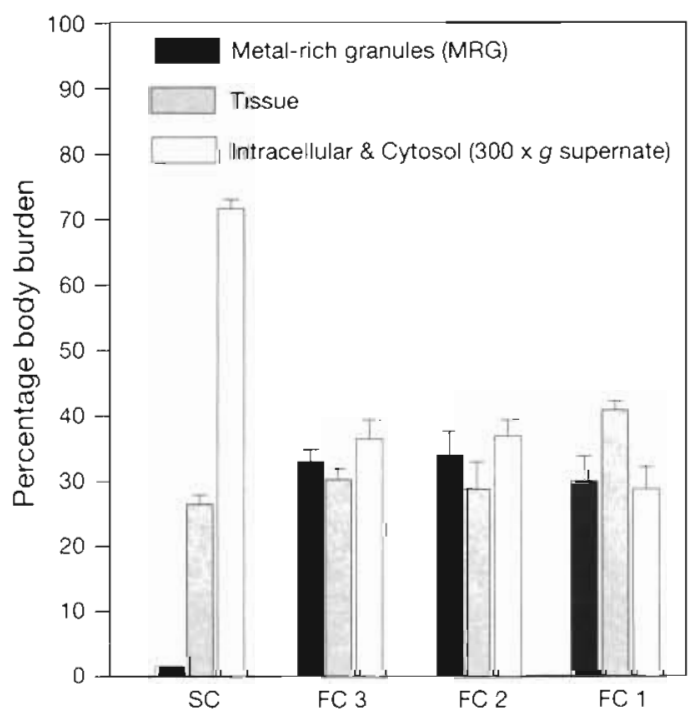

Fig. 6. Limnodrilus hoffmeisteri. Percentage subcellular ${ }^{109} \mathrm{Cd}$ distributions ( $\mathrm{n}=4$; mean \pm SE) of South Cove (SC) and Foundry Cove (FC 3, FC 2 and FC 1) worms exposed for $7 \mathrm{~d}$ to Hudson River water containing a spike of ${ }^{109} \mathrm{Cd}$. Subcellular fractions (metal-rich granules [MRG], tissue and supernates [intracellular/cytosol]) were obtained through homogenization, differential centrifugation and tissue digestion procedures cellular ${ }^{109} \mathrm{Cd}$ distribution of $\mathrm{SC}$ worms was in marked contrast to this with $72 \%$ of accumulated ${ }^{109} \mathrm{Cd}$ being in the intracellular/cytosolic fraction and only $2 \%$ in MRG. Further fractionation of both SC and FC 1 worms revealed that 57 and $11 \%$ of total ${ }^{109} \mathrm{Cd}$ was bound in the respective cytosols, while worms from both sites had $\sim 15 \%$ associated with the intracellular fraction (Fig. 7a). SC worms had $\sim 34 \%$ of the accumulated ${ }^{109} \mathrm{Cd}$ bound in the heat-stable (MT-like) protein fraction, while FC 1 worms had $-8 \%$ in this fraction. SC and FC 1 worms had similar proportions ( $65 \%)$ of cytosolic bound ${ }^{109} \mathrm{Cd}$ associated with the heat-stable (MT-like) protein fraction. On a concentration basis, it is clear that the MRG fraction of FC 1 worms is an important site for $\mathrm{Cd}$ storage; this fraction contains nearly as much ${ }^{109} \mathrm{Cd}$ as was accumulated by SC worms (Fig, 7b).

The MRG fractions isolated from FC 1 and SC worms were examined with a compound microscope and numerous granules of varying sizes 110 to $30 \mu \mathrm{m}$ in diameter) were found in the MRG fraction of FC 1 worms. One of the larger granules is shown in Fig. 8 . This granule is approximately $30 \mu \mathrm{m}$ in diameter and is composed of many smaller granules $(\sim 1 \mu \mathrm{m})$. These isolated granules were similar in size and appearance to those found via electron microprobe analysis in other Foundry Cove Limnodrilus hoffmeisteri (Klerks \& Bartholomew 1991). No granules were found in the corresponding fraction of SC worms.
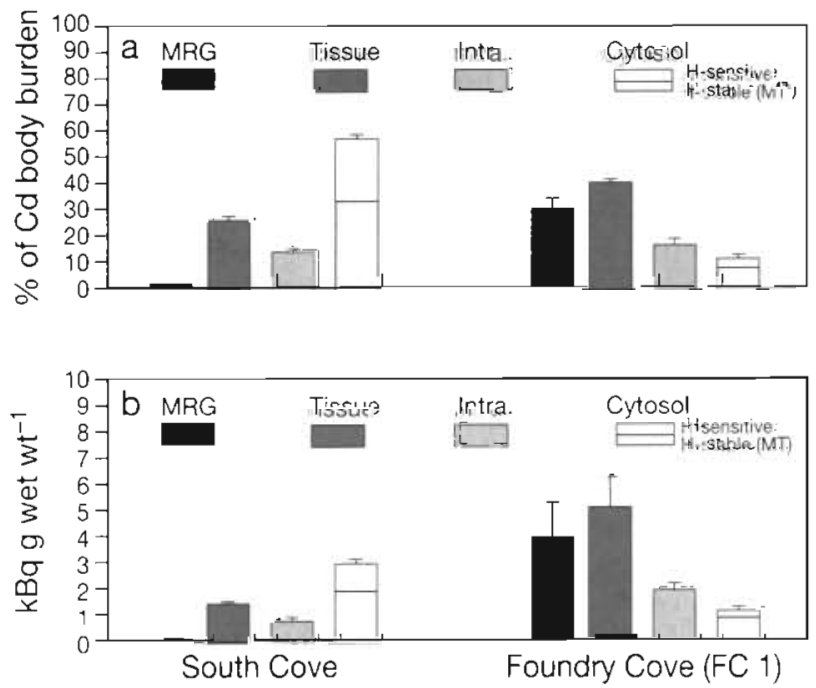

Fig. 7. Limnodrilus hoffmeisteri. (a) Percentage and (b) amount (kBq g wet wt ${ }^{1}$ ) of ${ }^{109} \mathrm{Cd}(\mathrm{n}=4$; mean $\pm \mathrm{SE}$ ) among subcellular fractions (metal-rich granules [MRG], tissue, intracellular [Intra.], and heat-sensitive and heat-stable [MT-like] proteins) of South Cove (SC) and Foundry Cove (FC 1) worms exposed for $7 \mathrm{~d}$ to Hudson River water containing a spike of ${ }^{109} \mathrm{Cd}$. Subcellular fractions were obtained through homogenization, differential contrifugation and tissue digestion procedures 


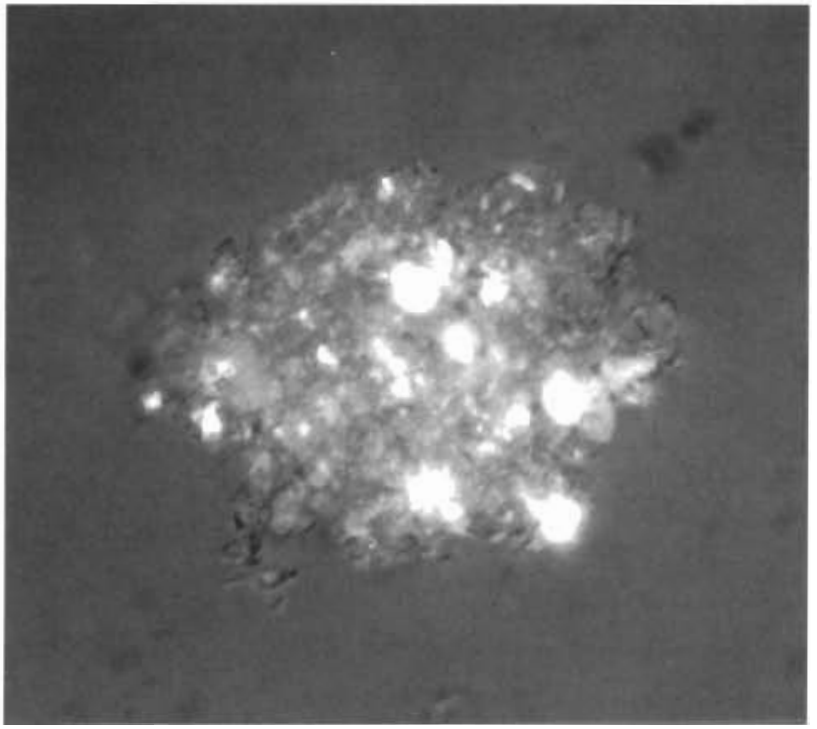

Fig. 8. Limnodrilus hoffmeisteri. Metal-rich granule (MRG) isolated from the debris fraction of Foundry Cove (FC 1) worms. This granule is approximately $30 \mu \mathrm{m}$ in diameter and is composed of many small granules

There was good agreement between the subcellular distributions of both ${ }^{109} \mathrm{Cd}$ and stable $\mathrm{Cd}$ for FC 1 and $\mathrm{FC} 3$ worms. The percentages of stable $\mathrm{Cd}$ in the unfractionated intracellular/cytosolic fractions (i.e. $300 \times g$ supernatant) of FC 1 and FC 3 worms were 38 and $24 \%$, respectively. The $\mathrm{Cd}$ concentrations of these fractions were $214 \mathrm{\mu g} \mathrm{g}$ wet $\mathrm{wt}^{-1}$ for FC 1 worms and $80 \mu \mathrm{g} \mathrm{g}$ wet $\mathrm{wt}^{-1}$ for $\mathrm{FC} 3$ worms. The $\mathrm{Cd}$ concentration of the unfractionated tissue and MRG fractions (i.e. 300 $\times g$ pellet) were 354 and $264 \mu \mathrm{g} \mathrm{Cd} \mathrm{g} \mathrm{wet} \mathrm{wt}^{-1}$, respectively. Combining the $\mathrm{Cd}$ concentrations of these fractions yield total Cd body burdens of $568 \mu \mathrm{g} \mathrm{g}$ wet $\mathrm{wt}^{-1}$ for worms from $\mathrm{FC} 1$ and $344 \mu \mathrm{g} \mathrm{g}$ wet $\mathrm{wt}^{-1}$ for those from FC 3. As a comparison, in related work worms from South Cove have been shown to have a Cd body burden of $-1 \mu \mathrm{gg}$ wet $\mathrm{wt}^{-1}$ with approximately $0.44 \mu \mathrm{g}$ $g$ wet $w t^{-1}$ being in the biologically available, intracellular and cytosolic fractions (Wallace 1996).

\section{Bioavailability of cadmium sequestered by oligochaetes}

Loss of ${ }^{109} \mathrm{Cd}$ from shrimp fed FC 1 and SC worms was in 2 components; an initial rapid loss (production of ${ }^{109} \mathrm{Cd}$-labeled feces) followed by a gradual loss (metabolic depuration of absorbed ${ }^{109} \mathrm{Cd}$ ) (Fig. 9). Following the ingestion of $\mathrm{FC} 1$ and $\mathrm{SC}$ worms, shrimp produced radiolabeled feces for the first $12 \mathrm{~h}$. Physiological depuration of absorbed Cd was responsible for the loss of ${ }^{109} \mathrm{Cd}$ after $24 \mathrm{~h}$. Cd absorption efficiencies

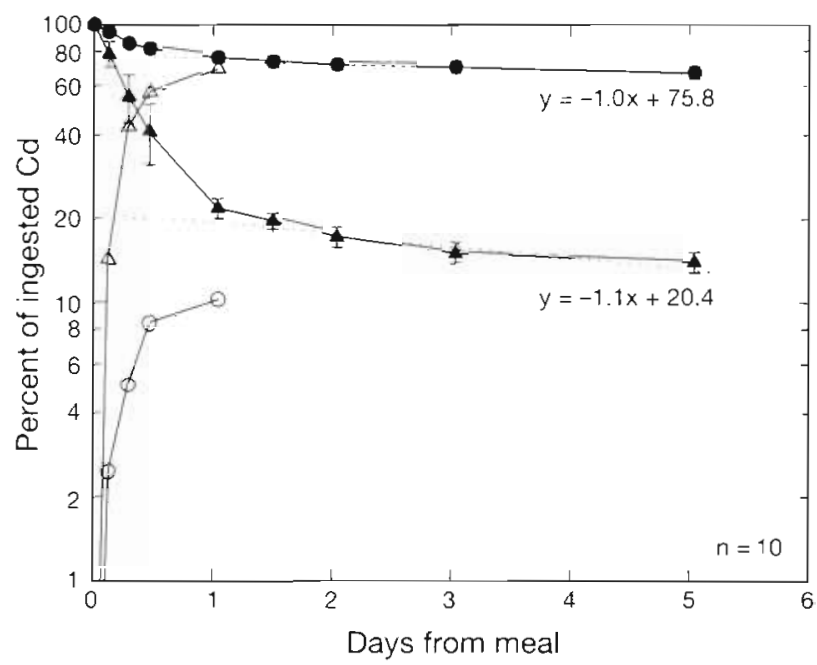

Fig. 9. Percentage retention (filled symbols; mean \pm SE) and egestion (open symbols) of ${ }^{109} \mathrm{Cd}$ by Palaemontes pugio fed ${ }^{109} \mathrm{Cd}$-labeled South Cove $(\bullet, 0)$ or Foundry Cove (FC 1) $(\bullet, \Delta)$ Limnodrilus hoffmeisteri. Linear regressions (dashed lines) were fit to the physiological loss components of each retention curve (i.e. time $>24 \mathrm{~h}$ ) and $y$-intercepts give an estimate of ${ }^{109} \mathrm{Cd}$ absorption efficiency. Egestion curves were caiculated by dividing the cumulative ${ }^{100} \mathrm{Cd}$ egested by all shrimp in the sample by the total ${ }^{109} \mathrm{Cd}$ ingested by these shrimp. Egestion curves are plotted only up until $24 \mathrm{~h}$; no ${ }^{109} \mathrm{Cd}$-labeled fecal material was produced beyond this point

were therefore determined by fitting linear regressions to the physiological loss components of each curve (36 to $121 \mathrm{~h}$ ). The $y$-intercept gives an estimate of the percentage of ingested ${ }^{109} \mathrm{Cd}$ initially absorbed by shrimp (Benayoun et al. 1974). It is this initial pool of absorbed $\mathrm{Cd}$ which is the source of the physiologically depurated ${ }^{109} \mathrm{Cd}$. This method of calculating absorption efficiency assumes a constant rate of depuration from this initial pool of absorbed metal. Shrimp fed FC 1 worms absorbed an estimated $20.4 \%$ of the ingested ${ }^{109} \mathrm{Cd}$, while shrimp fed SC worms absorbed $75.8 \%$. These absorption efficiencies were significantly different $(\mathrm{p}<$ $0.001)$. Regardless of Cd dietary source, shrimp depurated the absorbed ${ }^{109} \mathrm{Cd}$ at similar rates $\left(\sim 1 \% \mathrm{~d}^{-1}\right)$.

\section{DISCUSSION}

This study, in conjunction with previous work, directly relates evolution of $\mathrm{Cd}$ resistance in prey to alterations in metal trophic transfer to a predator (Klerks \& Levinton 1989, Klerks \& Bartholomew 1991, Wallace \& Lopez 1997). Our goal in this work was to determine how chronic $\mathrm{Cd}$ exposure and the evolution of Cd resistance in the aquatic oligochaete Limnodrilus hoffmeisteri influences $\mathrm{Cd}$ trophic transfer to the grass shrimp Palaemonetes pugio. This goal was realized by determining that oligochaetes inhabiting a metal con- 
taminated cove and those from an adjacent unpolluted cove differ with respect to $\mathrm{Cd}$ tolerances, accumulation, subcellular distributions and bioavailability to predators. This work was made possible by the extreme contamination of Foundry Cove with $\mathrm{Cd}$ by discharge from a $\mathrm{Ni}$-Cd battery plant. The range in sediment $\mathrm{Cd}$ concentrations found along the transect in this present study $\left(-200\right.$ to $\left.\sim 2000 \mu \mathrm{g} \mathrm{g} \mathrm{dry} \mathrm{wt}^{-1}\right)$ was in good agreement with, though lower than, those found in previous studies (Kneip \& Hazen 1979, Knutson et al. 1987). The highest sediment Cd concentration found in this study, although extreme by 'normal' standards was roughly 2 orders of magnitude lower than the highest ever found in the cove $(225000 \mu \mathrm{g} \mathrm{Cd}$ $\mathrm{g}$ dry $\mathrm{wt}^{-1}$ ) (Knutson et al. 1987).

Klerks \& Levinton (1989) demonstrated that Limnodrilus hoffmeisteri in Foundry Cove evolved resistance to $\mathrm{Cd}$ in as few as 4 generations. While we did not conduct experiments to assess the inheritance of Cd resistance, FC 1 worms were more tolerant of Cd than SC worms, and survivorship was similar to genetically resistant worms studied by Klerks (1987). The type of mortality exhibited by FC 1 and SC worms supports the assertion of Klerks \& Levinton (1989) that Cd resistance in Foundry Cove $L$. hoffmeisteri was possible because of high genetic heterogeneity in the 'preexposed' population. The gradual and consistent loss of SC worms once they start to succumb to the $\mathrm{Cd}$ exposure gives some indication as to the extent of this variability in Cd tolerance.

The enhanced accumulation of Cd by Foundry Cove worms over South Cove worms is indicative of internal storage and detoxification of Cd by MT-like proteins and MRG (Roesijadi 1980, Brown 1982, Klerks \& Bartholomew 1991). The magnitude of ${ }^{109} \mathrm{Cd}$ accumulation by Foundry Cove oligochaetes in this study is similar to that obtained by Klerks (1987) for other Foundry Cove oligochaetes. The similarity in $\mathrm{Cd}$ accumulation among Foundry Cove worms (FC 1, FC 2 and FC 3) also suggests a uniform mechanism for $\mathrm{Cd}$ uptake. Other metal-resistant organisms exhibit increased metal accumulation. Copper-resistant populations of the polychaete Nereis diversicolor and the isopod Asellus meridians accumulate more metal than nonresistant conspecifics and both species stored the metal in granular form (Bryan \& Hummerstone 1971 , Brown 1977). Additionally, the difference between the mean and median concentration factors for FC 2 and FC 3 worms further suggests great variability in the physiological mechanisms of $\mathrm{Cd}$ accumulation within these 2 populations. It could be speculated that these worms exhibiting such a high accumulation of $\mathrm{Cd}$ might already possess the ability to successfully detoxify $\mathrm{Cd}$ and that they would produce the offspring most capable of coping with the contamination.
The most obvious differences between the subcellular ${ }^{109} \mathrm{Cd}$ distributions of Foundry Cove (FC 1, FC 2 and FC 3) and SC worms are the lack of MRG, as well as the greater importance of the intracellular/cytosol fraction for ${ }^{109} \mathrm{Cd}$ storage in $\mathrm{SC}$ worms. The similarity in the proportions of cytosolic ${ }^{109} \mathrm{Cd}$ bound to the MT-like protein fraction of FC 1 and $\mathrm{SC}$ worms is not surprising. In other studies, after a $6 \mathrm{~d}$ exposure to the extremely high concentration of $8.9 \mu \mathrm{M}$, no discernible difference could be found between nonresistant South Cove and Cd-resistant Foundry Cove worms with regard to the proportion of cytosolic Cd bound to MTlike proteins (Klerks \& Bartholomew 1991). The formation of MRG was therefore cited as a likely reason for the resistance (Klerks \& Bartholomew 1991). In the present study both FC 1 and SC worms produced heatstable MT-like proteins, but only FC 1 worms produced $M R G$; it was these worms that were more tolerant of $\mathrm{Cd}$. The relation between MRG production and increased metal tolerance has been noted elsewhere. The isopod Asellus meridians from a Cu-polluted environment had increased Cu-tolerance and produced Cu-rich granules (Brown 1977); a Cu-resistant strain of the fungus Saccharomyces ellipsoideus contained Curich granules (Ashida 1965); and a Cu-resistant population of the polychaete Nereis diversicolor produced Cu-rich granules (Bryan \& Hummerstone 1971).

Cadmium binding to MT-like proteins in Limnodrilus hoffmeisteri, however, may have a role in conferring resistance. MT plays a key role in metal transport, and the relationship between MT and transport of metal to sites of MRG production is likely to be important. Copper, $\mathrm{Cd}, \mathrm{Hg}$ and $\mathrm{Zn}$ bound to $\mathrm{MT}$ in the kidney of the mussel Mytilus edulis become incorporated into granules (George 1983). Metal bound to MT in the digestive gland of Mytilus galloprovincialis becomes incorporated into lysosomes and is transformed into insoluble thionein polymers, a likely precursor of MRG (Viarengo et al. 1987). Metal binding to MT and subsequent transport to the endoplasmic reticulum and Golgi system, common sites for MRG production, has been described (Simkiss 1981, Brown 1982, George 1982).

Cadmium bound to the tissue fraction, which was composed of epidermis and intestinal epithelium, accounted for similar proportions of the total $\mathrm{Cd}$ absorbed by Foundry Cove and South Cove worms. This could be reflective of a surface-area relationship or a limited number of binding sites (Hare 1992, Wallace \& Lopez 1996). However, because of the undifferentiated nature of this fraction it is difficult to completely understand its importance in Cd storage. The similar percentages of ${ }^{109} \mathrm{Cd}$ in the intracellular fractions of FC 1 and SC worms suggests that this fraction also has a limited number of binding sites. The rela- 
tively low proportion of ${ }^{109} \mathrm{Cd}$ in this fraction is consistent with previous studies demonstrating the negligible role of the intracellular fraction in Cd storage (Jenkins \& Mason 1988, Klerks \& Bartholomew 1991. Wallace \& Lopez 1996, 1997).

The similarity among subcellular distributions of Foundry Cove worms is consistent with similarities in $\mathrm{Cd}$ accumulation. Even though there was an order of magnitude difference in sediment $\mathrm{Cd}$ levels between FC 1 and the other 2 stations (FC 2 and FC 3 ) there were no strong differences among Foundry Cove worms with respect to subcellular $\mathrm{Cd}$ distribution or $\mathrm{Cd}$ accumulation. What might explain this absence of a concentration dependence on metal uptake and storage is a 'threshold' mediated change from the nonresistant to the resistant state. This change might then be accompanied by the changes in metal uptake and subcellular storage; in all other respects, FC $1 \mathrm{Cd}$ resistant worms were physiologically similar to FC 2 and FC 3 worms.

This threshold may be simply related to sediment $\mathrm{Cd}$ concentration and would lie between the $\mathrm{Cd}$ concen-

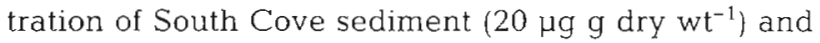
that of FC 3 sediment $\left(250 \mu g \mathrm{~g}\right.$ dry $\left.\mathrm{wt}^{-1}\right)$. However, it is more likely related to the amount of $\mathrm{Cd}$ which is biologically available for uptake in the sediment or pore water; this biologically available metal however is difficult to quantify (Luoma 1989). Alternatively, there could be a saturating process, whereby, irrespective of the total sediment $\mathrm{Cd}$, there is a rate-limiting step for metal uptake into the worm, such as binding of $\mathrm{Cd}$ within one fraction of the organism, or even entry into the dissolved phase in the porewater. The exact details of this process still remain to be elucidated.

The trophic transfer of $\mathrm{Cd}$ is clearly influenced by how $\mathrm{Cd}$ is stored within the body of prey organisms. The difference between ${ }^{109} \mathrm{Cd}$ absorption by shrimp fed FC 1 and SC worms is caused by differences in the oligochaetes' subcellular ${ }^{109} \mathrm{Cd}$ distributions. The intracellular/cytosolic fraction of oligochaetes is the bioavailable fraction for shrimp, and the percentages of $\mathrm{Cd}$ in these combined fractions agree very well with respective absorption efficiencies: $76 \%$ for SC worms and $-30 \%$ for FC 1 worms (Wallace \& Lopez 1996, 1997). Cadmium bound in the MRG is unavailable because these granules are insoluble in the gut of the shrimp (Mason \& Nott 1981, Simkiss 1981, Nott \& Nicolaidou 1993, Wallace \& Lopez 1997). Limnodrilus hoffmeisteri possess 2 types of granules: high density granules, possibly $\mathrm{CdS}$, as well as low density granules consisting of a mixed $\mathrm{Ca}-\mathrm{Cd}$-Fe phosphate (Klerks \& Bartholomew 1991j. Recent work indicates that the gut $\mathrm{pH}$ of Palaemonetes pugio is approximately 5.10 (M. Ahrens), a value which is comparable with similar crustaceans (DeGiusti et al. 1962, Van Weel 1970). CdS would not dissolve at these pHs (Gong et al. 1977). Cd in the mixed $\mathrm{Ca}$-Cd-Fe phosphate granules should also be unavailable because similar granules isolated from bivalves are insoluble (Simkiss 1981). Metals in some granules are bioavailable; magnesium/calcium carbonate granules in herbivorous gastropods were leached of component metals during digestion by carnivorous gastropods, but phosphate granules were relatively unaffected (Nott \& Nicolaidou 1990). Additionally, it is likely that tissue-bound $\mathrm{Cd}$ is unavailable because oligochaete cuticle is not fully hydrolyzed during digestion (Krasnoper 1989).

The possibility of a threshold in $\mathrm{Cd}$ concentration required to induce the mechanism(s) of $\mathrm{Cd}$ resistance in oligochaetes could have profound implications for $\mathrm{Cd}$ trophic transfer. Nonresistant oligochaetes store a majority of their absorbed $\mathrm{Cd}$ in the readily bioavailable intracellular and cytosolic fractions, while resistant worms sequester $\mathrm{Cd}$ withın biologically unavailable MRG. The interplay between sediment Cd levels, $\mathrm{Cd}$ accumulation by oligochaetes and differences in subcellular $\mathrm{Cd}$ distributions could result in nonresistant worms having a biologically available $\mathrm{Cd}$ concentration equal to or greater than that of $\mathrm{Cd}$ resistant worms. This situation would arise if nonresistant worms had a total $\mathrm{Cd}$ body burden only 3 times lower than that of FC 3 worms (108 vs $344 \mu \mathrm{gg}$ wet $\left.\mathrm{wt}^{-1}\right)$. The concentration of $\mathrm{Cd}$ in the biologically available fractions, the intracellular/cytosolic fractions, of these Cd-resistant and nonresistant would be the same $\left(-80 \mu \mathrm{g} g\right.$ wet $\left.\mathrm{wt}^{-1}\right)$.

Even though Foundry Cove was recently dredged sediment $\mathrm{Cd}$ levels are still on the order of $80 \mu \mathrm{g} g$ dry $\mathrm{wt}^{-1}$ and $\mathrm{Cd}$ is still being exported to the Hudson River (Wallace \& Levinton unpubl., L. Suatoni unpubl.). Additionally, most of the outer portion of Foundry Cove has Cd concentrations greater than $20 \mu \mathrm{g} g$ dry wt $^{-1}$ (South Cove sediment) but less than $250 \mu \mathrm{g} \mathrm{g}$ dry $\mathrm{wt}^{-1}$ (FC 3 sediment) (Bower et al. 1978). The sediment $\mathrm{Cd}$ concentrations of Foundry Cove are therefore still within this hypothetical threshold region. In order to fully understand the impact of the dredging of Foundry Cove on its inhabitants it would be useful to determine $\mathrm{Cd}$ resistance and concentrations of biologically available $\mathrm{Cd}$ in Limnodrilus hoffmeisteri presently inhabiting the cove. This could indicate whether the dredging of Foundry Cove reduced or increased the potential for $\mathrm{Cd}$ trophic transfer. The former would result if sediment $\mathrm{Cd}$ levels are low enough that the accumulation of $\mathrm{Cd}$ in the oligochaetes biologically available fraction is substantially lower than in previous populations. The latter would result if only enough contaminated sediment was removed from the cove so that the oligochaetes were released from the pressures selecting for $\mathrm{Cd}$ resistance. This loss in resistance might also 
result in the loss of the ability to sequester $\mathrm{Cd}$ into insoluble, biologically unavailable MRG hence leading to proportionally more metal being stored in the biologically available intracellular/cytosolic fractions. Recent studies indicate that $L$. hoffmeisteri presently inhabiting Foundry Cove are slightly less tolerant than previous populations and have $\mathrm{Cd}$ body burden on the order of 13 to $52 \mu \mathrm{g} \mathrm{g} \mathrm{dry} \mathrm{wt}^{-1}\left(\sim 2\right.$ to $6 \mu \mathrm{g} \mathrm{g}$ wet $\left.\mathrm{wt}^{-1}\right)$ (L. Suatoni unpubl.). It is presently unknown if there have also been changes in the worms' subcellular $\mathrm{Cd}$ distributions and how these changes might impact the trophic transfer of $\mathrm{Cd}$ in this ecosystem.

The amount of $\mathrm{Cd}$ bound to the biologically available fraction of Foundry Cove oligochaetes ranged from 80 to $210 \mu \mathrm{g} \mathrm{g}$ wet $\mathrm{wt}^{-1}$ (FC 3 and FC 1). Even though this biologically available Cd only constitutes roughly 24 to $38 \%$ of the worm's total Cd, the body burden available for trophic transfer is still extremely high. The question of whether these Cd body burdens of Foundry Cove Limnodrilus hoffmeisteri are high enough to cause $\mathrm{Cd}$ toxicity in Palaemonetes pugio is the focus of a related study (Wallace 1996). That work indicates that in response to a Cd-contaminated diet of Foundry Cove oligochaetes, $P$. pugio exhibits sublethal toxicity as evidenced by the production of $\mathrm{Cd}$-binding $\mathrm{MT}$ proteins and reductions in prey capture (Wallace 1996).

\section{CONCLUSIONS}

This work has shown that evolved Cd resistance alters Cd accumulation, which, in turn, influences the subcellular $\mathrm{Cd}$ distribution within Limnodrilus hoffmeisteri. These changes in the subcellular $\mathrm{Cd}$ distribution of $L$. hoffmeisteri result in drastic alterations in Cd bioavailability to Palaemonetes pugio. Increased Cd accumulation by resistant worms is linked to the storage of Cd into insoluble MRG. Although both nonresistant and resistant worms use heat-stable MT-like proteins for the storage of $\mathrm{Cd}$, nonresistant worms do not store absorbed Cd in MRG. The absence of MRG in nonresistant worms leads to a high proportion of accumulated $\mathrm{Cd}$ being stored in the cytosol, probably resulting from the induction of MT Because protein bound metal is readily available to predators, this leads to the efficient transfer of Cd to shrimp. In contrast, the storage of $\mathrm{Cd}$ by resistant worms into MRG alters $\mathrm{Cd}$ trophic transfer by reducing the bioavailability of this toxic metal. The production of MRG by Cd-resistant worms, however, is not sufficient enough to prevent substantial Cd trophic transfer to shrimp, because a portion of the Cd accumulated by these worms is also stored in the biologically available cytosolic and intracellular fractions. The concentration of this biologically available Cd still turns out to be far greater than that found in the nonresistant, South Cove worms. Determining the toxicity to predators of this biologically sequestered metal and understanding effects on ecosystem function are the logical next steps in this series of studies linking the impacts of a metal polluant at multiple levels of biological organization.

Acknowledgements. The authors thank Randall Young for his invaluable assistance in collecting oligochaetes without which this work could not have been conducted. We also thank Jo Kurdziel for assisting with the toxicity bioassays. Nicholas Fisher, Marius Brouwer and Gordon Taylor are all thanked for their valuable assistance in the laboratory and for comments on earlier versions of this manuscript. The comments of Daniel Cain and 4 anonymous reviewers were also very helpful. The Department of Ecology and Evolution of SUNY at Stony Brook is thanked for the use of their equipment. Portions of this research were supported by The Hudson River Foundation for Science and Education. This manuscript represents contribution 1106 from the Marine Sciences Research Center, SUNY at Stony Brook, and contribution 1015 from the Program in Ecology and Evolution, SUNY at Stony Brook.

\section{LITERATURE CITED}

Antonovics J, Bradshaw AD, Turner RG (1971) Heavy metal tolerances in plants. Adv Ecol Res 7:1-85

Ashida J (1965) Adaptation of fungus to metal toxicants. Annu Rev Phytopathol 3:153-174

ASTM (1980) Standard practice for conducting acute toxicity tests with fishes, macro-invertebrates, and amphibians. ASTM, (Am Soc Test Mater) E 729-80

Bebianno MJ, Langston WJ (1992) Metallothionein induction in Littorina littorea (Mollusca: Prosobranchia) on exposure to cadmium. J Mar Biol Assoc UK 72:329-342

Bell SS, Coull BC (1978) Field evidence that shrimp predation regulates meiofauna. Oecologia 35:141-148

Benayoun G, Fowler SW, Oregioni B (1974) Flux of cadmium through euphausiids. Mar Biol 27:205-212

Bonacina C, Bonomi G, Monti C (1989) Density-dependent processes in cohorts of Tubifex tubifex, with special emphasis on the control of fecundity. Hydrobiologia 180 : $135-141$

Bower PM, Simpson HJ, Williams SC, Li YH (1978) Heavy metals in sediments of Foundry Cove, Cold Spring, New York. Environ Sci Tech 12(6):683-687

Bradshaw A (1952) Populations of Agrostis tenuis resistant to lead and zinc poisoning. Nature 169:1089

Brinkhurst RO, Jamieson BGM (1971) Aquatic Oligochaeta of the world. Oliver and Boyd, Edinburgh

Brouwer $M$, Schlenk D, Huffman Ringwood A, BrouwerHoexum $T$ (1992) Metal-specific induction of metallothionein isoforms in the blue crab Callnectes sapidus in response to single- and mixed- metal exposure. Arch Biochem Biophys 291(2):461-468

Brown BE (1977) Uptake of copper and lead by a metaltolerant isopod Asellus meridianus Rac. Freshwat Biol 7: $235-244$

Brown BE (1982) The form and function of metal-containing 'granules' in invertebrate tissues. Biol Rev Camb Philos Soc 57:621-667

Bryan GW, Hummerstone LG (1971) Adaptation of the polychaetes Nereis diversicolor to estuarine sediments con- 
taining high concentrations of heavy metals. I. General observations and the adaptation to copper J Mar Biol Assor UK 51:845-863

Canli M, Furness RW (1995) Mercury and cadmium uptake from seawater and from food by the norway lobster Nephrops norvegicus. Environ Toxicol Chem 14(5): $819-828$

Chapman PM, Farrell MA, Brinkhurst RO (1982) Relative tolerances of selected aquatic oligochaetes to individual pollutants and environmental factors. Aquat Toxicol 2:47-67

DeGiusti DL, Beigelman E, Stanley D (1962) A comparison of the $\mathrm{pH}$ values of the anatomical areas of the digestive tract of the amphipods Hyalella azteca (Saussure) and Gammarus limnaeus (Smith). Trans Am Micro Soc 81:262-264

George SG (1982) Subcellular accumulation and detoxification of metals in aquatic animals. In: Vernberg WB (ed) Physiological mechanisms of marine pollutant toxicity. Academic Press, New York, p 3-55

George SG (1983) Heavy metal detoxification in Mytilus kidney-an in vitro study of $\mathrm{Cd}$ - and $\mathrm{Zn}$-binding to isolated tertiary lysosomes. Comp Biochem Physiol 76C:59

Gong H, Rose AW, Suhr NH (1977) The geochemistry of cadmium in some sedimentary rocks. Geochim Cosmochim Acta 41:1687-1692

Hare L (1992) Aquatic insects and trace metals: bioavailability, bioaccumulation, and toxicty. Crit Rev Toxicol 22(5/6): $327-369$

Hazen RE, Kneip TJ (1980) Biogeochemical cycling of cadmium in a marsh ecosystem. In: Nriagu JO (ed) Cadmium in the environment. Part I. Ecological cycling. John Wiley and Sons, New York, p 399-424

Hoffman CP Jr (1980) Growth and reproduction of Palaemonetes puglo Holthius, and P. vulgaris (Say) populations in Canary Creek Marsh, Delaware. MSc thesis, University of Delaware, Lewes

Jenkins KD, Mason AZ (1988) Relationships between subcellular distributions of cadmium and perturbations in reproduction in the polychaete Neanthes arenaceodentata. Aquat Toxicol 12:229-244

Klerks PL (1987) Adaptation to metals in benthic macrofauna PhD dissertation, State University of New York, Stony Brook

Kierks PL, Bartholomew PR (1991) Cadmium. accumulation and detoxification in a $\mathrm{Cd}$-resistant population of the oligochaete Limnodrilus hoffmeisteri. Aquat Toxicol 19:97-112

Klerks PL, Levinton JS (1989) Rapid evolution of metal resistance in a benthic oligochaete inhabiting a metal-polluted site. Biol Bull (Woods Hole) 176:135-141

Klerks PL, Weis JS (1987) Genetic adaptation to heavy metals in aquatic organisms: a review. Environ Pollut 45:173-205

Kneip TJ, Hazen RE (1979) Deposit and mobility of cadmium in a march-cove ecosvtem and the relation to cadmium concentration in biota. Environ Health Perspect 28:67-73

Knowlton RE (1973) Occurance of the grass shrimp, Palaemonetes pugio in southern Maine. Marine Nature, Maine Audubon Council (March), Brunswick

Knutson AB, Klerks PL, Levinton JS (1987) The fate of metalcontaminated sediments in Foundry Cove, New York. Environ Pollut 45: 291-304

Krasnoper EV (1989) Quantitative count of Tubificidae (Oligochaete) in the nutrition of fish. Hydrobiologia 25(1):91-96

Lee ET (1980) Statıstical methods for survival data analysis. Life Time Learning Publications, Belmont, CA

Levinton JS (1980) Cienetic divergence in estuaries. In: Kennedy VS (ed) Estuarine perspectives. Academic Press, New York, p 509-520

Luoma SN (1989) Can we determine the biological avail- ability of sediment-bond trace elements? Hydrobiologla 176/177:376-396

Martinez DE, Levinton JS (1996) Adaptation to hesivis metals in the oligochaete Limnodrilus hoffmeisteri: evidence for the control by one gene. Evolution 50(3):1339-1343

Mason AZ, Jenkins KD (1991) Effects of camdium bioavailability on the cytoplasmic distribution of cadmium in Neanthes arenaceodentata. Bull Mar Sci 48(2):524-529

Mason AZ, Nott JA (1981) The role of intracellular biomineralized granules in the regulation and detoxification of metals in gastropods with special reference to the marine prosobranch Littorina littorea. Aquat Toxicol 1:239-256

Nixon SW, Oviatt CA (1973) Ecology of a New England salt marsh. Ecol Monogr 43:463-498

Nott JA, Nicolardou A (1989) Metals in gastropods - metabolism and bioreduction. Mar Environ Res 28:201-205

Nott JA, Nicolaidou A (1.990) Transfer of metal detoxification along marine food chains. J Mar Biol Assoc UK 70:905-912

Nott JA, Nicolaidou A (1.993) Bioreduction of zinc and manganese along a molluscan food chain. Comp Blochem Physiol 104A $\{2\}: 235-238$

Reinfelder JR, Fisher NS (1991) The assimilation of elements incested by marine copepods. Science 251:794-796

Reinfelder JR, Fisher NS (1994) The assimilation of elements ingested by marine planktonic bivalve larvae. Limnol Oceanogr 39(1):12-20

Resource Engineering (1983) Preliminary site background data analysis of Foundry Cove, prepared for Vinson and Elkins. Resource Engineering, Houston

Roesijadi G (1980) The significance of low molecular weight, metallothionein-like proteins in marine invertebrates: Current status, Mar Environ Res 4:167-179

Roesijadi G (1992) Metallothioneins in metal regulation and toxicity in aquatic animals. Aquat Toxicol 22:81-114

Roessijadi G, Klerks PL (1989) Kinetic analysis of cadmium binding to metallothionein and other intracellular ligands in oyster gills. J Exp Zool 251(1): 1- 12

Sadiq M (1992) Cadmium in marine environments. In: Sadiq $M$ (ed) Toxic metal chemistry in marine environments. Marcel Dekker, Inc, New York, p 1.06-153

Silverman H, Steffens WL, Dietz TH (1.983) Calcium concretions in the gills of freshwater mussel serve as a calcium reservoir during periods of hypoxia. J Exp Biol 227:177-189

Simkiss K (1981) Calcium, pyrophosphate and cellular pollution. Trends Biochem Sci 3:111-113

Simpson WR (1981) A critical review of cadmium in the marine environment. Prog Oceanogr 10:1-70

Tessier A, Campbell PGC, Bisson M (1979) Sequential extraction procedure for the speciation of particulate trace metals. Anal Chem 51:844-851

Van Weel PB (1970) Digestion in crustacea. In: Florkin M, Scheer BT (eds) Chemical zoology, Vol 5. Academic Press, New York, p 97-115

Viarengo A, Moore MN, Mancinelli G, Mazzucotelli A, Pipe RK, Farrar SV (1987) Metallothioneins and lysosomes in metal toxicity and accumulation in marine mussels: effects of cadmium in the presence and absence of phenanthrene. Mar Biol 94:251-257

Wallace WG (1992) The trophic transter of biologically sequestered cadmium from the oligochaete Limnodrilus hoffmeisteri to the grass shrimp Palaemonetes pugio. MSc thesis, State University of New York, Stony Brook

Wallace WG (1996) A.cclimation and adaptation to pollutants: effects metal trophic transfer. Ph.D dissertation, State University of New York, Stony Brook

Wallace WG, Lopez GR (1996) Relationship between the subcellular cadmium distribution in prey and cadmium. 
trophic transfer to a predator. Estuaries 19(4):923-930

Wallace WG, Lopez GR (1997) Bioavailability of biologically sequestered cadmium and the implications of metal detoxification. Mar Ecol Prog Ser 147:149-157

Welsh BL (1975) The role of grass shrimp, Palaemonetes pugio, in a tidal marsh ecosystem. Ecology 56:513-530

Edrtorial responsibility: Otto Kinne (Editor),

Oldendorf/Luhe, Germany
Williams AB (1974) Marine flora and fauna of the Northeastern United States. Crustacea: Decapoda. NOAA Tech Rep NMFS Circ 389:1-50

Wood CE (1967) Physioecology of grass shrimp, Palaemonetes pugio, in the Galveston Bay estuarine system. Contrib Mar Sci 12:54-70

Submitted: December 17, 1997; Accepted: July 24, 1998

Proofs received from author(s): September 29, 1998 